\title{
Analisis Efesiensi dan Efektivitas Pengelolaan Keuangan Daerah Pemerintah Provinsi Jambi
}

\author{
Fathiyah \\ Fakultas Ekonomi Universitas Batanghari Jambi \\ Correspondence email: fathiyah_zaky@yahoo.co.id
}

\begin{abstract}
The purpose of this study is to analyze the level of efficiency and effectiveness of regional financial management of the Provincial Government of Jambi. The analytical tool used in this study is the analysis of efficiency ratios and effectiveness ratios with research data in the form of secondary data derived from the Jambi Provincial Government Budget Realization Report for 2015-2019. Then the results of the study are given an assessment based on the criteria listed in the Decree of the Minister of Home Affairs No. 690,900,327 of 1996. The conclusion from the results of this study is that based on the calculation results obtained that during the last 5 years the level of efficiency of the regional financial management of the Jambi Provincial Government fluctuated with an average level of efficiency of $96.90 \%$ and in the criteria of less efficient, whereas for the level of effectiveness it was an average of 98.45\% in the effective criteria, but in the last 2 years the effectiveness continues to increase in the highly effective criteria.
\end{abstract}

Keywords: Budget Realization Report; Efficiency; Effectiveness

\section{PENDAHULUAN}

Terbitnya undang-undang nomor 23 tahun 2014 tentang Pemerintah Daerah terkait dengan otonomi dan desentralisasi adalah pemberian kewenangan yang luas kepada setiap pemerintah Provinsi dan Kabupaten/Kota dalam menyelenggarakan semua urusan daerah. Pemberian otonomi dan desentralisasi ini diharapkan dapat meningkatkan efisiensi, efektivitas dan akuntabilitas pemerintah daerah untuk terciptaanya good governance.

Untuk mewujudkan good governance tersebut salah satu unsur penting dalam penyelenggaraan pemerintah dan pembangunan di daerah adalah dimanfaatkannya sistem pengelolaan keuangan daerah secara berdaya guna dan berhasil guna. Hal tersebut diharapkan agar sesuai dengan aspirasi pembangunan dan tuntutan masyarakat yang semakin berkembang saat ini. Agar tuntutan masyarakat untuk mencapai kesejahteraan dapat dicapai diperlukan pengelolaan keuangan daerah yang optimal. (Moenek dan Suwanda, 2019)
Pengelolaan keuangan daerah adalah program kerja suatu daerah dalam bentuk angka-angka dengan menyusun, merencanakan, melakasanakan, melaporkan, mempertanggung jawabkan dan pengawasan terhadap keuangan daerah yang berkaitan dengan Anggaran Pendapatan dan belanja Daerah (APBD). Perencanaan dan penyusunan APBD harus sesuai dengan kebutuhan penyelenggaraan pemerintahan dan kemampuan pendapatan daerah. Penyusunan APBD harus berpedoman pada Rencana Kerja Tahunan Daerah dalam rangka mewujudkan pelayanan kepada masyarakat yang lebih baik.

APBD yang disusun oleh pemerintah daerah terus mengalami perubahan dan pertumbuhan setiap tahunnya menyesuaikan dengan pembiayaan untuk mendanai Pembangunan dan pemberian pelayanan kepada masyarakat yang di wujudkan dalam program dan kegiatan. Untuk mengetahui perubahan dan tingkat pertumbuhan APBD Provinsi Jambi dalam 5 tahun terakhir seperti tertera pada tabel 1 dibawah ini :

Tabel 1. Pertumbuhan Realisasi Penerimaan dan Pengeluaran Pemerintah Provinsi Jambi Tahun 2015 - 2019

\begin{tabular}{cccccc}
\hline Tahun & Realisasi Penerimaan $(\mathbf{R p )}$ & r $(\boldsymbol{\%})$ & Realisasi Pengeluaran $(\mathbf{R p )}$ & r $(\%)$ & - \\
2015 & $3.129 .704 .823 .875,76$ & - & $3.425 .751 .341 .964,75$ & $(3,83)$ \\
2016 & $3.394 .795 .872 .563,54$ & 8,47 & $3.294 .484 .968 .672,84$ & 10,13 \\
2017 & $3.914 .671 .728 .293,41$ & 15,31 & $3.628 .173 .423 .832,88$ & $(2,85)$ \\
2018 & $4.412 .464 .565 .281,27$ & 12,72 & $3.524 .780 .175 .187,41$ & 36,87 \\
2019 & $4.575 .192 .849 .736,33$ & 3,69 & $4.824 .366 .351 .412,74$ & $\mathbf{1 0 , 0 8}$ \\
\hline
\end{tabular}

Sumber : Laporan Realisasi Anggaran Pemerintah Provinsi Jambi, Tahun 2015 - 2019

Hasil perhitungan pertumbuhan pada tabel 1 diatas dapat lihat bahwa pertumbuhan realisasi penerimaan Pemerintah Provinsi Jambi selama 5 tahun terkahir berfluktuasi dan cenderung terjadi penurunan dengan rata-rata nilai pertumbuhan sebesar $10,05 \%$, begitu juga dengan pertumbuhan realisasi pengeluaran juga mengalami fluktuasi dengan rata-rata pertumbuhan sebesar $10,08 \%$. 
Berdasarkan dari hasil analisis tabel tersebut juga dapat dijelaskan bahwa selama 5 tahun terakhir pada sisi realisasi penerimaan terus mengalami penurunan pertumbuhan dan pada pada sisi realiasasi pengeluaran ada kenaikan pertumbuhan yang sangat tajam pada satu tahun terakhir, artinya ada ketidakseimbangan antara tingkat pertumbuhan penerimaan dengan pertumbuhan pengeluaran. Sehingga dapat disimpulkan bahwa ada potensi ketidak efisienan dalam pengelolaan keuangan daerah pada Pemerintah Provinsi Jambi, namun walaupun terjadi penurunan pertumbuhan pada sisi penerimaan tetapi secara nominal realisasi penerimaan dalam 2 tahun terakhir mengalami peningkatan yang cukup tajam dan ini mengindikasikan bahwa efektivitas pengelolaan keuangan Pemerintah Provinsi Jambi berpotensi efektif. Tetapi sebesar apakah efisiensi dan efektivitasnya maka perlu dilakukan penelitian terlebih dahulu.

Penelitian tentang efisiensi dan efektivitas pengelolaan keuangan daerah ini pernah dilakukan oleh Novlie Manopo dkk dengan judul penelitian Analisis efisiensi dan efektivitas pengelolaan Keuangan Daerah Kabupaten Minahasa Tenggara (20..) yang menghasilkan kesimpulan bahwa sistim pengelolaan keuangan daerah di Kabupaten Minahasa Utara kurang efisien tetapi efektivitas pengelolaan keuangan daerahnya masuk pada kriteria sangat efektif. Penelitian yang sama dilakukan oleh Vera dkk dengan judul penelitian Analisis Efisiensi dan efektivitas Kemandirian pengelolaan keuangan daerah di Kabupaten Minahasa Utara (20..) menghasilkan kesimpulan bahwa efisiensi pengelolaan keuangan di Kabupaten Minahasa Utara rata-rata diatas $75 \%$ (efisien)dan efektivitas kinerjanya mencapai angka rata-rata $90 \%$.

Selanjutnya penelitian yang dilakukan oleh Miguel de Araujo dkk dengan judul penelitian Efektivitas dan Efisiensi Penerimaan Daerah Kabupaten (Distrik) Dili yang menghasilkan kesimpulan bahwa tingkat efektivitas penerimaan pendapatan Kabupaten (Distrik) Dili tergolong sangat efektif dan efisien. Maka berdasarkan penjelasan dan penelitian sebelumnya penulis tertarik untuk melakukan penelitian yang sama yaitu bagaimanakah efisiensi dan efektivitas pengelolaan keuangan daerah Pemerintah Provinsi Jambi Tahun 2015 -2019 .

Adapun tujuan dari penelitian ini adalah untuk menganalisis tingkat efisiensi dan efektivitas pengelolaan keuangan daerah Pemerintah Provinsi Jambi Tahun 2015 - 2019.

\section{Pengertian dan Azas Umum Pengelolaan Keuangan Daerah}

Menurut Halim (2012) keuangan daerah dapat diartikan sebagai semua hak dan kewajiban yang dapat dinilai dengan uang, demikian pula segala sesuatu baik yang berupa uang maupun barang yang dapat dijadikan kekayaan daerah sepanjang belum dimiliki oleh
Negara/daerah yang lebih tinggi serta pihak-pihak lain sesuai ketentuan peraturan perundang-undangan yang berlaku.

Peraturan Pemerintah Nomor 12 Tahun 2019 tentang pengelolaan keuangan daerah menyebutkan bahwa asas umum pengelolaan keuangan daerah adalah sebagai berikut:

1. Keuangan daerah harus dikelola secara tertib, taat pada peraturan perundang-undangan, secara efisien, ekonomis, efektif, transparan dan bertanggung jawab dengan memperhatikan azas keadilan

2. Pengelolaan keuangan daerah dilaksanakan dalam suatu sistim yang terintegrasi yang diwujudkan dalam APBD yang setiap tahun ditetapkan dengan peraturan Daerah.

Menurut Suparmoko (2002) Anggaran Pendapatan dan Belanja Daerah (APBD) adalah suatu alat perencanaan mengenai pengeluaran dan penerimaan dimasa yang akan datang yang umumnya disusun untuk satu tahun. Anggaran merupakan alat kontrol atau pengawasan terhadap penerimaan dan pengeluaran dimasa yang akan datang.

\section{Indikator Pengelolaan Keuangan Daerah}

Menurut Chabib dan Rohchamsyah (2010) menyebutkan bahwa prinsip pengelolaan keuangan daerah diperlukan untuk mengontrol kebijakan keuangan daerah yang meliputi beberapa unsur sebagai berikut :

1. Akuntabilitas

2. Value for money

Dengan prinsip setiap pengeluaran harus berorientasi ekonomis, efesiensi dan Efektivitas

3. Kejujuran dalam mengelola keuangan publik

4. Potensi Kerugian daerah

5. Transparansi

6. Administrasi

7. Pengendalian

\section{Efisiensi dan Efektivitas}

Mardiasmo (2004) mendefenisikan efisiensi adalah pencapaian output yang maksimum dengan input tertentu atau penggunaan input terendah untuk mencapai output tertentu. Efisiensi merupakan perbandingan input/output yang dikaitkan dengan standar kinerja atau target yang telah ditetapkan. Sedangkan Efektivitas adalah tingkat pencapaian hasil program dengan target yang ditetapkan atau dengan kata lain efektivitas merupakan perbandingan antara outcome dengan output.

Pengertian efektivitas menurut Hans Kartika Hadi dalam Agoes Sukirno (2000) adalah produk akhir dalam suatu kegiatan operasi telah mencapai tujuannya baik ditinjau dari segi kualitas hasil kerja, kuantitas hasil kerja maupun batas waktu yang ditargetkan. Sedangkan efisiensi didefenisikan sebagai bertindak dengan cara yang dapat meminimalisir kerugian atau pemborosan sumber daya dalam melaksanakan atau menghasilkan sesuatu. 


\section{Pengukuran Efisiensi}

Efisiensi diukur dengan rasio antara output dengan input, semakin besar output dibanding input semakin tinggi tingkat efisiensi suatu organisasi Mardiasmo, 2004), Efisiensi dapat dirumuskan sebagai berikut :

Rasio Efisiensi $=\frac{\text { Biaya Yang dikeluarkan untuk Mendapat PAD }}{\text { Realisasi Penerimaan PAD }} \times 100 \%$

Berdasarkan rumusan tersebut penilaian efisiensi dikategorikan sangat efisien apabila hasil perhitungan dibawah $60 \%$.

\section{Pengukuran Efektivitas}

Efektivitas adalah ukuran keberhasilan sebuah organisasi dalam mencapai tujuannya. Efektivitas tidak menyatakan tentang berapa besar biaya yang telah dikeluarkan dalam mencapai tujuan tersebut tetapi efektivitas hanya melihat suatu program atau kegiatan telah mencapai tujuan yang telah ditetapkan.(Mardiasmo, 2004).

Efektivitas merupakan hubungan antara output dengan tujuan, maka semakin besar kontribusi output terhadap pencapaian tujuan semakin efektif organisasi, program atau kegiatan. Efektivitas lebih fokus pada pencapaian hasil (outcome), Efektivitas dirumuskan sebagai berikut (Mahmudi, 2007)

Rasio Efektivitas $=\frac{\text { Realisasi Penerimaan PAD }}{\text { Target Penerimaan PAD yang ditetapkan }} \times 100 \%$

Berdasarkan rumusan ini penilaian efektivitas dinyatakan sangat efektif apabila hasil perhitungannya diatas $100 \%$.

\section{METODE}

\section{Jenis dan Sumber Data}

Jenis data yang digunakan dalam penelitian ini adalah data sekunder yang berasal dari laporan Realisasi Anggaran Pemerintah Provinsi Jambi Tahun 2015 2019 yang disusun oleh Badan keuangan Daerah provinsi Jambi.

\section{Defenisi dan Pengukuran Variabel} adalah:

Defenisi dan pengukuran variabal penelitian ini

1. Efisiensi, Pengukuran tingkat efisiensi dilihat dari sisi antara penerimaan dan pengeluaran dengan formula perhitungannya adalah sebagai berikut (Mardiasmo, 2004)
Rasio Efisiensi $=\frac{\text { Realisasi Pengeluaran }}{\text { Realisasi Penerimaan }} \times 100 \%$

Semakin kecil Rasio nya maka semakin efisien pengelolaan keuangan daerah tersebut

2. Efektivitas, Pengukuran tingkat efektivitas dilihat dari sisi antara realisasi penerimaan dengan target penerimaan dengan formula perhitungannya adalah sebagai berikut (Mardiasmo, 2004)

Rasio Efektivitas $=\frac{\text { Realisasi Penerimaan }}{\text { Target Penerimaan }} \times 100 \%$

Semakin besar rasionya maka semakin efektif pengelolaan keuangan daerah tersebut.

\section{Metode Analisis}

Metode yang digunakan dalam menganalisis penelitian ini adalah metode analisis tabel dalam menghitung tingkat efisiensi dan tingkat efektivitas dengan menggunakan kriteria penilaian berdasarkan Keputusan Menteri Dalam Negeri Nomor 690.900.327 Tahun 1996 tentang pedoman penilaian kinerja keuangan seperti pada table berikut ini ;

Tabel 2. Kriteria Kinerja Keuangan Berdasarkan Rasio Efisiensi

\begin{tabular}{cc}
\hline Persentase Kinerja Keuangan & Kiteria \\
\hline$>100 \%$ & Tidak Efisien \\
$90 \%-100 \%$ & Kurang Efisien \\
$80 \%-90 \%$ & Cukup Efisien \\
$60 \%-80 \%$ & Efisien \\
$<60 \%$ & Sangat Efisien \\
\hline
\end{tabular}

Dan untuk penilaian kriteria kinerja keuangan berdasarkan tingkat tingkat efektivitas dapat dilihat dari table 3 berikut ini

Tabel 3. Kriteria Kinerja Keuangan Berdasarkan Rasio Efektivitas

\begin{tabular}{cc}
\hline Persentase Kinerja Keuangan & Kiteria \\
\hline $100 \%$ & Sangat Efektif \\
$90 \%-100 \%$ & Efektif \\
$80 \%-90 \%$ & Cukup Efektif \\
$60 \%-80 \%$ & Kurang Efektif \\
$<60 \%$ & Tidak Efektif \\
\hline
\end{tabular}

\section{HASIL DAN PEMBAHASAN \\ Analisis Efisiensi}

Dari hasil perhitungan tingkat efisiensi pengelolaan keuangan daerah Pemerintah Provinsi Jambi Tahun 2015 -2019 diperoleh hasil pada tabel 4 berikut ini: 
Tabel 4. Efisiensi Pengelolaan Keuangan Daerah Pemerintah Provinsi Jambi Tahun 2015 - 2019

\begin{tabular}{ccccc}
\hline Tahun & Realisasi Penerimaan (Rp) & Realisasi Pengeluaran (Rp) & Efisiensi (\%) & Kriteria \\
\hline 2015 & $3.129 .704 .823 .875,76$ & $3.425 .751 .341 .964,75$ & 109,46 & Tidak Efisien \\
2016 & $3.394 .795 .872 .563,54$ & $3.294 .484 .968 .672,84$ & 97,05 & Kurang Efisien \\
2017 & $3.914 .671 .728 .293,41$ & $3.628 .173 .423 .832,88$ & 92,68 & Kurang Efisien \\
2018 & $4.412 .464 .565 .281,27$ & $3.524 .780 .175 .187,41$ & 79,88 & Efisien \\
2019 & $4.575 .192 .849 .736,33$ & $4.824 .366 .351 .412,74$ & 105,45 & Tidak Efisien \\
& \multicolumn{2}{c}{ Rata-rata } & $\mathbf{9 6 , 9 0}$ & Kurang Efisien \\
\hline
\end{tabular}

Dari tabel diatas diperoleh kesimpulan bahwa tingkat efisiensi pengelolaan keuangan daerah Pemerintah Provinsi Jambi selama 5 tahun terakhir berfluktuasi dimana pada tahun 2015 dan 2019 justru masuk pada kriteria tidak efisien dengan tingkat efisiensi diatas 100\%, dan pada tahun 2016 dan 2017 tingkat efisiensi sebesar $97,05 \%$ dan $92,68 \%$ dengan kriteria kurang efisien. namun pada tahun 2018 ada peningkatan efisiensi sebesar $79,88 \%$ dan masuk pada kriteria efisien. Secara keseluruhan rata-rata tingkat efisiensinya adalah sebesar 96,90\% dengan kriteria kurang efisien.

Berdasarkan perhitungan rata-rata tingkat efisiensi dalam 5 tahun terakhir tersebut yang menghasilkan kriteria kurang efisien menunjukkan bahwa kinerja pemerintah Povinsi Jambi dalam mengelola keuangan daerah masih rendah dan belum optimal sehingga pencapaian output dari input yang sudah ditetapkan tidak maksimal.

\section{Analisis Efektivitas}

Dari hasil perhitungan tingkat efektivitas pengelolaan keuangan daerah Pemerintah Provinsi Jambi Tahun 2015 -2019 diperoleh hasil pada tabel 5 berikut ini:

Tabel 5. Efektivitas Pengelolaan Keuangan Daerah Pemerintah Provinsi Jambi Tahun 2015 - 2019

\begin{tabular}{ccccc}
\hline Tahun & Realisasi Penerimaan (Rp) & Realisasi Penerimaan (Rp) & Efisiensi (\%) & Kriteria \\
\hline 2015 & $3.259 .508 .050 .000,00$ & $3.129 .704 .823 .875,76$ & 96,02 & Efektif \\
2016 & $3.433 .921 .466 .750,82$ & $3.394 .795 .872 .563,54$ & 98,86 & Efektif \\
2017 & $4.233 .797 .487 .302,00$ & $3.914 .671 .728 .293,41$ & 92,46 & Efektif \\
2018 & $4.213 .996 .839 .621,44$ & $4.412 .464 .565 .281,27$ & 104,71 & Sangat Efektif \\
2019 & $4.566 .472 .026 .795,00$ & $4.575 .192 .849 .736,33$ & 100,19 & Sangat Efektif \\
& \multicolumn{2}{c}{ Rata-rata } & $\mathbf{9 8 , 4 5}$ & Efektif \\
\hline
\end{tabular}

Dari tabel diatas diperoleh kesimpulan bahwa tingkat efektivitas pengelolaan keuangan daerah pemerintah Provinsi Jambi selama 5 tahun terakhir berfluktuasi dan cenderung meningkat, dimana pada tahun 2015 - 2017 besaran efektivitasnya berkisar antara 92\% - 98\% dengan kriteria efektif dan pada 2 tahun terakhir yaitu tahun 2018 - 2019 meningkat diatas $100 \%$ dan masuk kriteria sangat efektif. Secara rata-rata keseluruhan tingkat efektivitasnya adalah sebesar 98,45\% dan kategori kriterianya adalah efektif.

Berdasarkan hasil kriteria tersebut diatas dapat disimpulkan bahwa kinerja Pemerintah Provinsi Jambi dalam mengelola keuangan daerah selama 5 tahun terakhir sudah baik dan cenderung terus meningkat, yang artinya pencapaian output berdasarkan input yang ditetapkan sudah optimal dan semakin baik.

\section{SIMPULAN}

Berdasarkan hasil pembahasan maka diperoleh kesimpulan sebagai berikut ;

1. Hasil Analisis Rasio efesiensi menunujukkan bahwa tingkat efisiensi pengelolaan keuangan daerah Pemerintah provinsi Jambi dalam 5 tahun berfluktuasi dengan rata-rata tingkat efisiensinya adalah sebesar 96,90\% dan masuk dalam kriteria kurang efisien. Artinya Kinerja pengelolaan keuangan daerah Pemerintah Provinsi Jambi masih sangat rendah dan belum optimal karena pencapaian ouput berbanding inputnya tidak maksimal.

2. Hasil Analisis Rasio efektivitas menunjukkan bahwa tingkat efektivitas pengelolaan keuangan daerah Pemerintah Provinsi Jambi dalam 5 tahun terakhir berfluktuasi cenderung meningkat dengan rata-rata tingkat efektivitasnya sebesar $98,45 \%$ dan masuk dalam kriteria efektif. Artinya kinerja pengelolaan keuangan Pemerintah Provinsi Jambi sudah baik dan cenderung terus meningkat, artinya pencapaian output berbanding input yang ditetapkan sudah optimal dan semakin baik.

\section{DAFTAR PUSTAKA}

Chabib Soleh dan Heru Rochmansjah, 2010, Pengelolaan Keuangan dan Barang Daerah, Penerbit Fokus Media, Bandung

Cecilia, Vera Sri Endah, Sri Murni dan Daisy M. Engka, Analisis Efisiensi dan Efektivitas Kemandirian Pengelolaan Keunagan Daerah di Kabupaten Minahasa Utara, 2015, Jurnal Pembangunan Ekonomi dan Keuangan Daerah, Fakultas Ekonomi Universitas Sam Ratulangi

De Araujo, Miguel, Ni Luh Putu wiagustini dan IB Anom Purbawangsa, 2018, Efektivitas Dan Efesiensi Penerimaan Daerah distrik Dili, EJournal Ekonomi dan Bisnis Universitas Udayana. 
Halim, Abdul dan Muhammad Syam Kusufi, 2012, Akuntansi Sektor Publik Akuntansi Keuangan Daerah, Penerbit Salemba Empat, Jakarta

Mahmudi, 2007, Manajemen Kinerja Sektor Publik, Penerbit UPP STIM YKPN, Yogyakarta

Mardiasmo, 2004, Efisiensi dan efektivitas, Penerbit Andy, Jakarta

Moenek, DR. Drs. Reydonnyzar dan DR. Dadang Suwanda, 2019, Good Governance Pengelolaan Keuangan Daerah, Penerbit Rosda, Bandung.

Manoppo, Novlie, Debby Ch. Rontisulu dan Sri Murni, 2019, Analisis Efisiensi dan Efektivitas Pengelolaan Keuangan Daerah Kabupaten Minahasa Tenggara, Jurnal Pembangunan Ekonomi dan Keuangan Daerah, Fakultas Ekonomi Universitas Sam Ratulangi

Sukirno, Agoes, 2000, Auditing, Penerbit Fakultas Ekonomi Universitas Indonesia, Jakarta

Suparmoko, M.A., 2002, Ekonomi Publik untuk Keuangan dan Pembangunan Daerah, Penerbit Andi, Yoyakarta.

Pemerintah Provinsi Jambi, Laporan Realisasi Anggaran Tahun 2015 - 2019.

Pemerintah Republik Indonesia, Peraturan Pemerintah Nomor 12 Tahun 2019 Tentang Pengelolaan Keuangan Daerah.

Pemerintah Republik Indonesia, Kepmendagri Nomor 690.900.327 Tentang Pedoman Penilaian Dan Kinerja Keuangan Pemerintah Daerah

Pemerintah Republik Indonesia, Undang-undang nomor 23 Tahun 2014 Tentang Pemerintah Daerah 